\title{
The moderating effects of managers' experience and gender on internationalization and firm performance of manufacturing enterprises in Turkey
}

\author{
Phan Anh Tu ${ }^{a^{*}}$, Do Thuy Huong ${ }^{a}$ and Phan Minh Triet ${ }^{\mathrm{b}}$
}

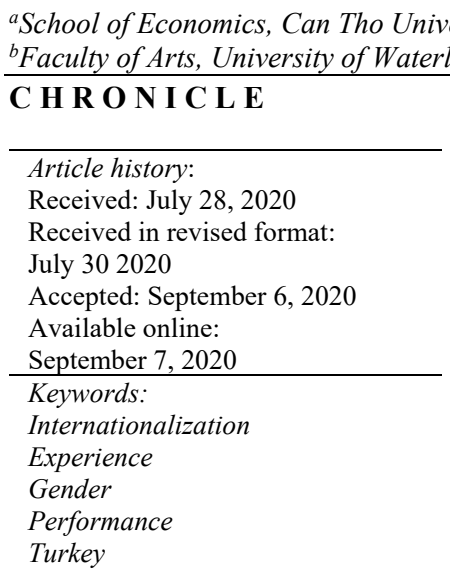

\section{Introduction}

Internationalization and efficiency of business operations have been a matter of great concern in the field of international business by scholars around the world for more than five decades. When expanding operations to global markets, companies have growth opportunities, can accumulate knowledge from foreign markets, and help businesses reduce production costs and incurring costs due to international environmental uncertainty (Contractor et al., 2007). However, internationalization also harms firm performance. For example, businesses will face risks and may face failure when expanding internationally (Benito-Osori et al., 2016). Although there have been many previous empirical studies on internationalization and business performance, the empirical results are often inconsistent due to differences in analytical method and research period, and sometimes contradictions lead to mixed conclusions. Most of these studies are conducted in countries with developed economies, and the research subjects are multinational companies. While many other empirical studies have found a linear relationship between internationalization and business performance of multinationals in the world and Taiwan (Hsu, 2006; Lin et al., 2011) and including the positive (negative) impact of internationalization on business performance of emerging market firms (Cuervo-Cazurra et al., 2018) and the U.S. market (Tashman et al. , 2019), Riahi-Belkaoui (1998) is one of the rare scholars who finds a non-linear relationship between the degree of internationalization and the business performance of multinational companies in the large-scale economy (USA).

\footnotetext{
* Corresponding author.

E-mail address: patu@ctu.edu.vn (P. A. Tu) 
The role of moderating variables in the relationship between internationalization and business performance has attracted interest, although quite rare since 2006, such as the study by Hsu et al. (2013). Furthermore, research on the manager's role is scarce. According to the Uppsala model, Vahlne and Johanson (2017) pointed out that managerial competence is viewed as an essential key in achieving growth and that managers play a vital role in making decisions on doing business in foreign markets. Upperechelons theory in organizations has shown that to manage complexity from international markets and ambiguity, the role characteristically of the manager in decision-making when processing information is vital. Adequate confidence is necessary (Herrmann \& Datta, 2006). Therefore, the study's question is whether or not and how the positive effect of internationalization on business performance will be enhanced or decreased when there is a moderating effect from the managers' personal characteristics.

This research will contribute to the literature review of internationalization by threefold: (1) provide additional empirical evidence for the theory of internationalization; (2) highlight a vital role of personal traits of the managers of the firms; (3) provide a particular research context, i.e., manufacturing enterprises in transition economies.

\section{Literature review}

Internationalization is the process by which businesses expand their business to foreign markets. Internationalization is a significant growth strategy for businesses when the domestic market is limited; internationalization helps companies grow their economic scope and scale, and at the same time, helps companies reduce input costs (Dunning, 1988). According to researchers, internationalization is also understood as the process of firms increasing their participation in foreign markets and making strategic decisions to increase international sales (George et al., 2005). When businesses participate in overseas markets, there will be many benefits, such as increasing knowledge about foreign markets, enhancing competitiveness through gaining practical experience, and exploiting local strategic assets (Ghoshal \& Bartlett, 1990). Expanding business operations to a new market also creates many challenges and increases costs for businesses, particularly regarding the legal liability of "foreigners" when doing business in another market (Hymer, 1976). Besides, to be successful in the international market, companies must understand the cultural characteristics of the market they want to participate in, to make product innovations suitable for the market. Therefore, for a business to be successful and limit the risks of uncertainty, the complexity and constant volatility of foreign markets depend significantly on the leading executive role. The business performance of a firm shows the firm's ability to use its resources to achieve its goals. Experimental results in the world have also demonstrated that the relationship between internationalization and business performance of enterprises in the period from 1998 to the first three months of 2020 is nonlinear (shape The $\mathrm{U}$, the inverted $\mathrm{U}$, the $\mathrm{S}$, and the $\mathrm{W}$ ), are sometimes linear (forward, inverse) and mixed relationship. Internationalization is also explained in the direction of considering the methods of entering the international market of the business, more clarification in the Uppsala model. The Uppsala model, also known as the "internationalization process" theory, was developed from Uppsala University by Johanson and Vahlne (1977). This model explains that the internationalization of a business can be divided into four stages of development: (1) no regular exports, (2) exports through independent representatives, (3) sales branches in foreign markets, and (4) production in international markets. Over the past four decades (from 1977 to 2017), Johanson and Vahlne have repeatedly developed the Uppsala model, the 2017 Uppsala model is their newest model, and the management ability is considered as a significant bottleneck in achieving growth (Vahlne \& Johanson, 2017). We argue that internationalization is a complicated business strategy and is tied to the business managers' decision or choice of doing business. A business manager is a unit of analysis. Upper-Echelon theory refers to groups of people with high social status (Hambrick, 2007) or top managers of the business, such as CEOs, senior managers, or top management team (board). Hambrick and Mason (1984) argued that firm performance is influenced by factors related to the manager's personal characteristics; personal opinions change the perceptions of the manager, and these affect the choice of a firm's business strategy (Hambrick, 2007). Many studies use Upper-Echelon theory to explain a firm's internationalization strategy related to the traits of managers such as experience (Cavusgil et al., 2012), education level, age (Herrmann \& Datta, 2005), gender (Ho et al., 2015).

Managerial experience. Management experience is measured by the number of years that the manager is working in the current position. As the number of years working increases also means that the number of managers' experience increases, knowledge accumulation during the working time will create experience and motivation for international business expansion. (Johanson \& Vahlne, 1977). A manager with knowledge accumulated increasingly after years of working in a leadership position creates valuable experiences in dealing with the complexities and uncertainties of international markets while overcoming the psychic distance associated with doing business in global markets (Johanson \& Vahlne, 2009). These experiences values motivate them to develop strategies and expand their business to new international markets (Tihayi et al., 2000). At the same time, managers' experience also directly affects the business results of firms in global markets (Athanassiou \& Nigh, 2000). Along with the expertise, knowledge of foreign cultures, as well as the selection of business methods of managers, will help businesses eliminate barriers of cultural differences through innovation and innovation product policies, brand promotion to suit the culture of each country.

Hypothesis $\mathrm{H}_{1}$ : Managerial experience will positively moderate the relationship between the degree of internationalization and firm performance. 
Managers'gender. Turkey is a country with a prosperous transition economy, and the Turkish government is always supportive of corporate business; it is trying to reinforce Islamic values, which could hinder the advancement of women in society (Burke, 2012). Some studies show that Men and Women in Turkey consider women as houseworkers, suitable for the role of motherhood (Kabasakal et al., 2004). Men are represented in the majority of the leadership roles in Turkey (Kabasakal et al., 2011), and women are not represented in the senior leadership ranks or the committee director of a business (Broadbridge, 2010). The empirical studies have shown that male managers bring more benefits to businesses than women (Fairlie \& Robb, 2009). Firms headed by women do not have the majority of the financial resources to be led by men (Williams, 2013). Since internationalization is a cost-effective strategy to maintain international relations and strengthen its position in the market, a business with a South manager is more suitable to engage in the process. Next, male managers face less discriminatory barriers and barriers and barriers to entry into international markets than Female managers (Brush et al., 2004). At the same time, ideological stereotypes against women also create doubts from new clients about women's performance and their ability to deliver quality products to international markets on time (Fernando, 2005). All of these make such a significant obstacle to the internationalization process if the manager is a female.

Hypothesis $\mathrm{H}_{2}$ : The female manager will negatively moderate the relationship between the degree of internationalization and firm performance.

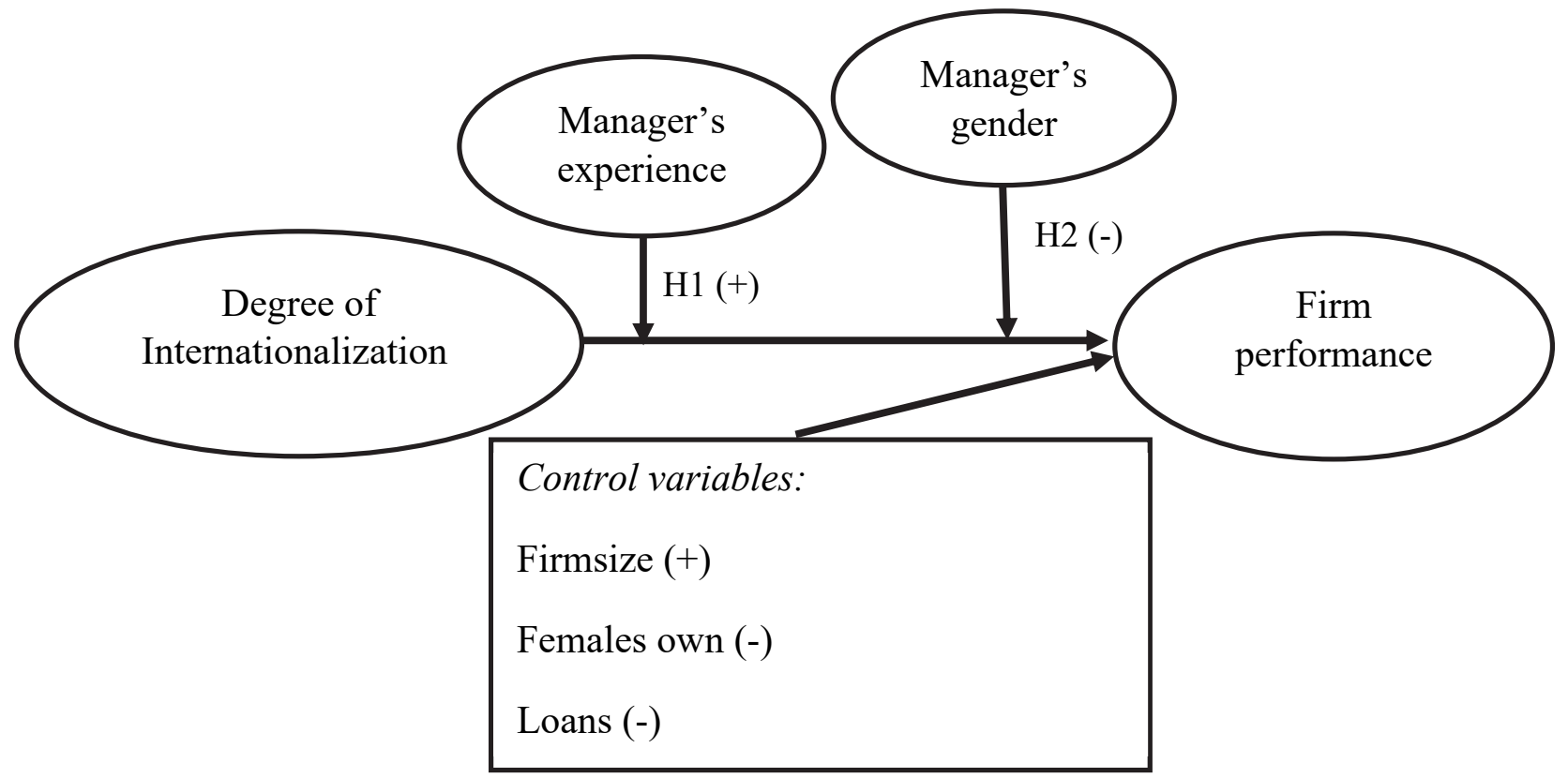

\section{Research method}

\section{Data}

This study uses secondary data sources on Turkey surveyed by the European Bank for Reconstruction and Development (EBRD), the European Investment Bank (EIB), and the World Bank (W.B.) on the business environment and business performance of 4,159 enterprises. The panel data set used in this study are firms are operating in the manufacturing and manufacturing sector of Turkey in 3 survey periods in 2018, January 2013 - December 2014 and September 9. 2018 - May 2019. The final sample used for analysis has 789 observations, including 263 processing and manufacturing enterprises.

\section{Estimation model}

The regression method with Feasible Generalized Least Squares (FGLS) is used to estimate the moderating effects on the relationship between the independent and dependent variables. The multicollinearity phenomenon is not a concern in this study (Hair et al., 2006) because the correlation coefficients in the Pearson correlation matrix of the variables are all less than 0.8, and the VIF index is below the "threshold" value 10.0. To choose between REM and FEM models, we conducted a Hausman test. Accordingly, with Prob $>$ chi $2=0.0714$ and greater than P-value $=0.05$ (accept H0 hypothesis), the REM model is more suitable than the FEM model. Then, the Lagrange test is used to check the heteroskedasticity of the REM model. As a result, it obtains Prob $>$ chibar $2=0.0000$ smaller than $\mathrm{P}$-value $=0.05$, so rejecting hypothesis $\mathrm{H}_{0}$ (homogeneous variance), the model exists the heteroscedasticity phenomena with significance level 0.05 . To cope with this issue, we use the Feasible Generalized Least Squares (FGLS) method as a method to correct this issue and thus increase the effectiveness of the estimation model.

The estimation model is constructed as follows: 
Dependent variable: $\mathrm{ROS}_{\mathrm{it}}$ is the Return on sales of the business performance of Turkish processing and manufacturing firms at time $\mathrm{t}$.

Independent variable: doi $\mathrm{i}_{\mathrm{it}}$ degree of internationalization of the firms.

Control variable: firmsize ${ }_{i t}$, femalesown ${ }_{\mathrm{it}}$ :, applyloans $\mathrm{it}_{\mathrm{it}}$, laborregu $_{\mathrm{it}}$ : labor regulation, eduwork $\mathrm{k}_{\mathrm{it}}$ : labor's education

Moderator variables: extm $_{\mathrm{it}}$ : managerial experience, gendertmit: lmanager gender

Interaction terms:

doiex $_{i}$ : the interaction between the degree of internationalization and management experience (measured by multiplying the doi variable and the extm variable),

doigeit: the interaction between the degree of internationalization and the gender of the leader (measured by multiplying the doi variable and the variable gendertm together).

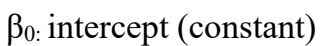

$\beta_{\mathrm{i}}$ : are the coefficients representing the marginal impact of factor $\mathrm{i}$ in the model,

$\mathrm{i}=1, \ldots \mathrm{N}$, where $\mathrm{N}$ is the number of firms in the sample; $\mathrm{t}=1, \ldots \mathrm{T}$, where $\mathrm{T}$ is the research period.

and $\varepsilon_{\mathrm{it}}$ is the random error of the model.

\section{Table 1}

Descriptions of variables

\begin{tabular}{|c|c|c|c|}
\hline Define & Symbol & Measure & Expected \\
\hline \multicolumn{4}{|c|}{ Dependent variable } \\
\hline Return on Sales & ROS & $\begin{array}{l}\text { The rate of profit on total sales } \\
\text { (Xiao et al., 2013) }\end{array}$ & \\
\hline \multicolumn{4}{|c|}{ Independent variables } \\
\hline \multirow{2}{*}{$\begin{array}{l}\text { Degree of } \\
\text { internationalization }\end{array}$} & \multirow{2}{*}{ doi } & $\begin{array}{l}\text { Percentage of export revenue over total revenue: } \\
\quad \% \text { direct export sales }+ \text { indirect export revenue }\end{array}$ & \multirow[t]{2}{*}{$(-)$} \\
\hline & & (Xiao et al., 2013; Gashi et al., 2014) & \\
\hline \multicolumn{4}{|c|}{ Moderator variables } \\
\hline Managerial experience & expertm & $\begin{array}{l}\text { Years of experience }=\text { years of managers in the manufacturing and processing } \\
\text { industry } \\
\text { (Johanson \& Vahlne, 1990) }\end{array}$ & $(+)$ \\
\hline Manager gender & gendertm & $\begin{array}{l}\text { Manager's gender, } 1=\text { Female, } 0=\text { Male } \\
\text { (Bathula, 2008) }\end{array}$ & $(+)$ \\
\hline \multicolumn{4}{|c|}{ Control variables } \\
\hline Firm size & firm size & $\begin{array}{l}\text { Number of employees in the firms } \\
0 \text { is small and medium-sized enterprise ( }>=5 \text { to }<=99 \text { employees), } 1 \text { is a large- } \\
\text { scale enterprise }(>=100 \text { people) } \\
\text { (Cerrato \& Piva, 2012) }\end{array}$ & $(+)$ \\
\hline Females business owners & femalesown & $\begin{array}{l}\text { Whether women own the business or not } \\
\text { Dummy variable }(1=\text { yes, } 0=\text { no) } \\
\text { (Fairli \& Robb, 2009) }\end{array}$ & $(-)$ \\
\hline Loans & applyloans & $\begin{array}{l}\text { Business with or without a loan } \\
\text { Dummy variable }(1=\text { Yes, } 0=\text { no) } \\
\text { (Hibbert, 2000; Erdogan, 2015) }\end{array}$ & $(-)$ \\
\hline Labor regulations & laborregu & $\begin{array}{l}\text { Likert-5 levels: "To what extent, labor regulations are an obstacle to business } \\
\text { operations." } \\
\text { 0: no obstacles 4: extremely obstacles } \\
\text { (Baykal \& Gunes, 2004; Almeida \& Carneiro, 2009) }\end{array}$ & $(+)$ \\
\hline Education level of labor & eduwork & $\begin{array}{l}\text { Likert-5 levels: "At what level, the education level of labor is an obstacle to the } \\
\text { operation of the business." } \\
\text { 0: no obstacles till 4: extremely obstacle } \\
\text { (Baykal \& Gunes, 2004) }\end{array}$ & $(-)$ \\
\hline
\end{tabular}

\section{Results and discussion}

Table 2 shows the results of the descriptive statistics of the variables in the research model. The average value of the return on sales of the business (ROS) is 43,412\%, the maximum value is $100 \%$, and the smallest amount is $-1994.94 \%$. The degree of 
internationalization, on average, reaches $0.293 \%$, with the highest value being $100 \%$ and the lowest $0 \%$. Moreover, the average of the managers' experience is about 23 years. Meanwhile, most of the managers are male rather than female (see Table 2).

Table 2

Descriptive statistics

\begin{tabular}{|c|c|c|c|c|c|c|c|}
\hline$\#$ & Variable name & Symbol & $\begin{array}{r}\text { Number of } \\
\text { observations }\end{array}$ & Mean & $\begin{array}{l}\text { Standard } \\
\text { deviation }\end{array}$ & Minimum & Maximum \\
\hline 1 & Return on Sales (ROS) (\%) & ros & 789 & 43,412 & 34,278 & $-199,94$ & 100 \\
\hline 2 & Degree of Internationalization (DOI) & doi & 789 & 0,293 & 0,368 & 0 & 100 \\
\hline 3 & Managerial experience & expertm & 789 & 23,099 & 12,047 & 2 & 70 \\
\hline 4 & Manager's gender & gendertm & 789 & 0,074 & 0,261 & 0 & 1 \\
\hline 5 & Firm size & firmsize & 789 & 0,274 & 0,446 & 0 & 1 \\
\hline 6 & Females own businesses & femalesown & 789 & 0,313 & 0,464 & 0 & 1 \\
\hline 7 & Loans & applyloans & 789 & 0,398 & 0,490 & 0 & 1 \\
\hline 8 & Labor regulation & laborregu & 789 & 1,137 & 1,280 & 0 & 4 \\
\hline 9 & Education level of labor & eduwork & 789 & 1,572 & 1,418 & 0 & 4 \\
\hline
\end{tabular}

Source: World Bank Enterprises Survey (2019)

Next, Table 3 presents the correlation matrix between pairs of variables in the model, Table 4 presents the regression results of 3 models Pooled OLS, REM, and FEM. Regression results with FGLS estimates are shown in Table 5.

Table 3

Description of the statistics and correlation table $(n=789)$

\begin{tabular}{|c|c|c|c|c|c|c|c|c|c|c|c|c|}
\hline Variables & Mean & S.D & VIF & 1 & 2 & 3 & 4 & 5 & 6 & 7 & 8 & 9 \\
\hline 1.Return on Sales & 43,412 & 34,278 & & 1 & & & & & & & & \\
\hline $\begin{array}{l}\text { 2.Degree of } \\
\text { internationalization }\end{array}$ & 0,293 & 0,368 & 5,03 & $-0,021^{\mathrm{ns}}$ & 1 & & & & & & & \\
\hline $\begin{array}{l}\text { 3. Managerial } \\
\text { experience }\end{array}$ & 23,099 & 12,047 & 1,68 & $0,011^{\text {ns }}$ & $0,012^{\text {ns }}$ & 1 & & & & & & \\
\hline 4.Manager's gender & 0,074 & 0,261 & 2,05 & $-0,031^{\text {ns }}$ & $0,078^{*}$ & $-0,069^{*}$ & 1 & & & & & \\
\hline 5.Firm size & 0,274 & 0,446 & 1,11 & $0,010^{\text {ns }}$ & $0,257^{* * *}$ & $0,069^{*}$ & $0,012^{\mathrm{ns}}$ & 1 & & & & \\
\hline $\begin{array}{l}\text { 6.Female business } \\
\text { owner }\end{array}$ & 0,313 & 0,464 & 1,16 & $-0,114^{* *}$ & $0,119^{* * *}$ & $0,058^{\text {ns }}$ & $0,312^{* * *}$ & $0,143^{* * *}$ & 1 & & & \\
\hline 7.Loans & 0,398 & 0,490 & 1,07 & $-0,165^{* * *}$ & $0,153^{* * *}$ & $0,033^{\text {ns }}$ & $-0,011^{\mathrm{ns}}$ & $0,134^{* * *}$ & $0,104^{* *}$ & 1 & & \\
\hline 8.Labor regulations & 1,137 & 1,280 & 1,73 & $0,082^{*}$ & $-0,087^{*}$ & $-0,089^{*}$ & $0,027^{\mathrm{ns}}$ & $-0,032^{\text {ns }}$ & $-0,087^{*}$ & $-0,121^{* * *}$ & 1 & \\
\hline $\begin{array}{l}\text { 9.Education level of } \\
\text { labor }\end{array}$ & 1,572 & 1,418 & 1,70 & $-0,012^{\mathrm{ns}}$ & $-0,048^{\text {ns }}$ & $-0,024^{\mathrm{ns}}$ & $0,065^{*}$ & $0,037^{\text {ns }}$ & $-0,047^{\mathrm{ns}}$ & $0,012^{\text {ns }}$ & $0,628^{* * *}$ & 1 \\
\hline
\end{tabular}

Table 4

Pooled OLS, REM, FEM models

\begin{tabular}{|c|c|c|c|}
\hline \multirow[t]{2}{*}{ Variables } & \multicolumn{3}{|c|}{ Return on sales: ROS } \\
\hline & Pooled OLS & REM & FEM \\
\hline Constant & $50,51^{* * *}(4,011)$ & $49,04^{* * *}(3,837)$ & $43,60^{* * *}(4,547)$ \\
\hline \multicolumn{4}{|c|}{ Control variables } \\
\hline Firm size & $2,913^{\text {ns }}(2,834)$ & $3,057^{\mathrm{ns}}(2,880)$ & $4,514^{\mathrm{ns}}(3,857)$ \\
\hline Female business owner & $-8,170^{* *}(3,138)$ & $-7,529^{* *}(2,723)$ & $-4,954^{\mathrm{ns}}(3,201)$ \\
\hline Loans & $-10,19^{* * *}(2,665)$ & $-9,378^{* * *}(2,513)$ & $-6,213^{*}(3.104)$ \\
\hline Labor regulations & $2,859^{*}(1,188)$ & $2,190^{\text {ns }}(1,225)$ & $-0,0262^{\text {ns }}(1,533)$ \\
\hline Education level of labor & $-1,937^{*}(0,984)$ & $-1,251^{\mathrm{ns}}(1,095)$ & $0,864^{\mathrm{ns}}(1,353)$ \\
\hline \multicolumn{4}{|c|}{ Main effect } \\
\hline Degree of internationalization & $-12,78^{\text {ns }}(8,368)$ & $-10,23^{\text {ns }}(7,167)$ & $-1,285^{\text {ns }}(8,513)$ \\
\hline Managerial experience & $-0,117^{\mathrm{ns}}(0,127)$ & $-0,092^{\text {ns }}(0,126)$ & $-0,016^{\mathrm{ns}}(0,146)$ \\
\hline Manager's gender & $10,21^{\mathrm{ns}}(5,860)$ & $11,15^{\text {ns }}(6,400)$ & $14,11^{\mathrm{ns}}(7,428)$ \\
\hline \multicolumn{4}{|c|}{ Moderator effect } \\
\hline $\begin{array}{l}\text { Degree of internationalization } \times \text { Managerial } \\
\text { experience }\end{array}$ & $0,727^{*}(0,316)$ & $0,621^{*}(0,279)$ & $0,296^{\text {ns }}(0,323)$ \\
\hline $\begin{array}{l}\text { Degree of internationalization } \times \text { manager's } \\
\text { gender }\end{array}$ & $-25,78^{\text {ns }}(13.998)$ & $-28,43^{* *}(10,965)$ & $-35,61^{* *}(12,880)$ \\
\hline \multirow[t]{4}{*}{ Number of observations } & 789 & 789 & 789 \\
\hline & $F(10,778)=5,04$ & Wald chi2 $(10)=41,86$ & $\mathrm{~F}(10,516)=1,70$ \\
\hline & Prob $>F=0,0000$ & Prob $>$ chi $2=0,0000$ & Prob $>F=0,0776$ \\
\hline & $\mathrm{R}^{2}=0.06221$ & $\mathrm{R}^{2}$ within $=0.0242$ & $\mathrm{R}^{2}$ within $=0,0319$ \\
\hline
\end{tabular}

Note: $\left({ }^{* *}\right) p<0.001,\left({ }^{* *}\right) p<0.01,(*) p<0.05$, (n.s) $p>0.1$ (non. significant), the values in parentheses are standard errors. 


\section{Table 5}

Feasible Generalized Least Squares (FGLS)

\begin{tabular}{|c|c|c|c|c|c|}
\hline \multirow[b]{2}{*}{ Variables } & \multicolumn{5}{|c|}{ Return on sales: ROS } \\
\hline & Model 1 & Model 2 & Model3 & Model 4 & Model 5 \\
\hline Constant & $48,93^{* *}(1,391)$ & $47,73^{* * *}(2,104)$ & $52,61^{* * *}(2,325)$ & $47,72^{* * *}(2,077)$ & $51,51^{* * *}(2,397)$ \\
\hline \multicolumn{6}{|l|}{ Control variables } \\
\hline Firm size & $5,959^{* * *}(1,445)$ & $5,647^{* * *}(1,501)$ & $4,106^{*}(1,632)$ & $4,487^{* *}(1,556)$ & $3,443^{*}(1,691)$ \\
\hline Female business owners & $-6,749^{* * *}(1,349)$ & $-6,616^{* * *}(1,461)$ & $-6,614^{* * *}(1,533)$ & $-6,106^{* * *}(1,537)$ & $-6,888^{* * *}(1,666)$ \\
\hline Loans & $-10,22^{* * *}(1,256)$ & $-9,354^{* * *}(1,502)$ & $-8,897^{* * *}(1,523)$ & $-9,901^{* * *}(1,544)$ & $-9,560^{* * *}(1,613)$ \\
\hline Labor regulation & $3,460^{* * *}(0,643)$ & $3,770^{* * *}(0,686)$ & $3,835^{* * *}(0,686)$ & $3,422^{* * *}(0.683)$ & $3,401^{* * *}(0,728)$ \\
\hline Education level of labor & $-2,347^{* * *}(0,530)$ & $-2,605^{* * *}(0,555)$ & $-2,436^{* * *}(0,598)$ & $-2,376^{* * *}(0,554)$ & $-2,245^{* * *}(0,629)$ \\
\hline \multicolumn{6}{|c|}{ Main effects } \\
\hline Degree of internationalization & & $-1,534^{\text {ns }}(1,900)$ & $-16,54^{* * *}(4,202)$ & $1,792^{\text {ns }}(2,087)$ & $-9,588^{*}(4,632)$ \\
\hline Managerial experience & & $\begin{array}{l}0,064^{\text {ns }} \\
(0,579)\end{array}$ & $-0,138^{\text {ns }}(0,077)$ & $0,057^{\mathrm{ns}}(0,058)$ & $\begin{array}{r}-0,096^{\mathrm{ns}} \\
(0,079)\end{array}$ \\
\hline Manager's gender & & $-0,933^{\text {ns }}(3,144)$ & $-0,885^{\text {ns }}(2,855)$ & $10,75^{*}(4,981)$ & $9,963^{*}(4,899)$ \\
\hline \multicolumn{6}{|c|}{ Moderator effects } \\
\hline $\begin{array}{l}\text { Degree of internationalization } \mathrm{x} \\
\text { Managerial experience }\end{array}$ & & & $0,647^{* * *}(0,167)$ & & $0,476^{* *}(0,177)$ \\
\hline $\begin{array}{l}\text { Degree of internationalization } \mathrm{x} \\
\text { Manager's gender }\end{array}$ & & & & $-24,65^{* * *}(6,616)$ & $-21,21^{* *}(6,837)$ \\
\hline Number of observations & 789 & 789 & 789 & 789 & 789 \\
\hline Wald chi2 & $191,24^{* * *}$ & $177,08^{* * *}$ & $178,64^{* * *}$ & $176,59^{* * *}$ & $149,12^{* * *}$ \\
\hline
\end{tabular}

Model 5 in Table 5 includes all the main variables in the research model, the value Prob $>$ chi $2=0.000$ shows the suitability of the model with actual data at $99 \%$ confidence level. All variables in model 5 are statistically significant, except for the variable of managerial experience $\left(\beta_{7}=-0.096\right)$. There are 4 variables positively correlated with the return on sale (ROS) including: firm size $\left(\beta_{1}=3,443\right)$, labor regulations $\left(\beta_{4}=3,401\right)$, manager's gender $\left(\beta_{8}=9,963\right)$, the interaction between the degree of internationalization and managerial experience $(\beta 7=0.476)$. They are statistically significant at $5 \%, 0.1 \%, 5 \%$, and $1 \%$. Nevertheless, the remaining variables have a negatively correlated with the return on sales (ROS): business owner is Female $(\beta 2=-6,888)$, loan $(\beta 3=-9,560)$, labor level $(\beta 5=-2,245)$, the degree of internationalization $(\beta 6=-9,588)$, the interaction between the degree of internationalization and the manager's gender $(\beta 10=-21.21)$ and all have statistical significance at $0.1 \%$, $5 \%$, and $1 \%$ level. According to model 5, there is a negative relationship between the degree of internationalization and firm performance, but it is insignificant. This connection is contrary to expectation. It is because internationalization is a risky process, and firms have to burden additional costs in which these costs exceed the benefits that the business achieves, leading to a decline in the firm performance. In the early stage of internationalization, the costs incurred will also increase because firms often focus on market exploration, enhancing knowledge learning, and experience in international markets (Johanson, \& Vahlne, 1977). At the same time, companies have to deal with obstacles and cost barriers such as the cost of the liability of "foreigners" (Hymer, 1976); the costs of adapting to cultures and institutions in different countries (Contractor et al., 2007); corporate governance and administration costs (Contractor et al., 2003); shipping costs and tariffs (Contractor et al., 2007).

Model 5 in Table 5 shows the interaction of internationalization level and leader experience (variable doiex) positively correlated. This result implies that the relationship between the degree of internationalization and the firm's business performance is strengthened as the managers' years of working experience increase. Therefore, hypothesis $\mathrm{H}_{1}$ has been accepted. Experience in management positions helps leaders gain knowledge and confidence in managing and managing businesses. Those things create the motivation for leaders to have strategies to develop products and expand business activities to international markets; the manager's experience also assists them in coping with the complexities and uncertainties of global markets; and directly affects the business performance of firms in international markets. Also, managers can use their experience to interact with partners in foreign markets better, contribute to building trust and enhancing the reputation and image of the business in mind and thereby providing to the elimination of barriers of distance (cultural, social and geographical) in the process of expanding cross-border business activities.

Besides, model 5 shows that the interaction between the degree of internationalization and manager's gender is negatively correlated with firm performance. The hypothesis $\mathrm{H}_{2}$ is hence supported. Hence, the relationship between the degree of internationalization and the firm's business performance will decline when the firm has a female manager, in contrast, a male manager will contribute to enhancing the positive effects of internationalization on the business performance. It can be explained that male managers are more successful than female leaders because, unlike women, men are not typically more focused on aspects such as risk reduction and risk aversion, and resilience, and higher risk tolerance (Maden, 2015). 
Internationalization plays a vital role as an increasingly necessary and valuable strategy for businesses (Hsu et al., 2013), and in particular, this strategy is even more relevant and essential for firms in a transition economy like Turkey. This study used Moderated Multiple Regression analysis (MMR) with the feasible general least-squares estimation (FGLS) method to find empirical evidence to support the hypotheses. Namely, the degree of internationalization has a more substantial positive influence on firm performance if the managers are males and have more managerial experience. The relationship between the degree of internationalization and firm performance may vary depending on the managerial characteristics of the firms. Therefore, firms may consider the personal traits of the managers of the firms carefully before they decide to expand the market in the global context. The results show several essential governance implications for corporate boards and managers who aspire to become senior managers in an international environment. First, to have a better performance, firms, or managerial boards of the firms may be better able to choose males and who have much experience than females and who have less experience in operating the internationalization process. Second, female managers may better improve their international management experience in order to cope with additional transaction costs in foreign countries such as the "newness" and the "liability of foreignness".

This study goes without limitations. First, this result is limited to manufacturing firms, so that it is difficult to generalize to different business sectors. Second, the number of female managers may depend on a particular culture, region, and the whole country, but the data shows inadequate. Future research should extend the scope of research space and time (phases of internationalization); consider further personal characteristics of the managers such as functional experience, education, age, marital status, concurrent rights in the business, foreign language ability, cultural contexts. Third, research in the future may pay attention to the influence of top managers' characteristics without considering how other members of the corporate board of directors affect the relationship between the degree of internationalization and business performance. Finally, scholars may use diversified indices to measure firm performance.

\section{References}

Athanassiou, N. \& Nigh, D. (2000). Internationalization, tacit knowledge and the top management teams of MNCs. Journal of International Business Studies, 31(3), 471-487.

Bathula, H. (2008). Board characteristics and firm performance: Evidence from New Zealand, AUT University, 128 pp.

Benito-Osorio, D., Colino, A., Guerras-Martín, L. Á., \& Zúñiga-Vicente, J. Á. (2016). The international diversificationperformance link in Spain: Does firm size really matter?. International Business Review, 25(2), 548-558.

Burke, R. J., Koyuncu., M., Singh., P., Alayoglu, N., \& Koyuncu, K. (2012). Gender differences in work experiences and work outcomes among Turkish managers and professionals,' Gender in Management: An International Journal, 27(1), 23-35.

Broadbridge, A. (2010). Women at the top in British retailing: plus ca change?. The Service Journal, 30, 1-25.

Brush, C., Carter, N., Gatewood, E., Greene, P., \& Hart, M. (2004). Clearing the hurdles: Women building high-growth businesses. FT Press.

Cavusgil, S., Kinight, G., \& Riesenberger, J. (2012). International Business, Pearson Education, NJ.

Cerrato, D., \& Piva, M. (2012). The internationalization of small and medium-sized enterprises: the effect of family management, human capital and foreign ownership. Journal of Management \& Governance, 16(4), 617-644.

Contractor, J. F., S. K. Kundu. \& C. -C. Hsu (2003), 'A three-stage theory of international expansion: The link between multinationality and performance in the service sector', Journal of International Business Studies, 34(1), 5-18.

Contractor, F. J., V. Kumar. \& S. K. Kundu. (2007). Nature of the relationship between international expansion and performance: The case of emerging market firms. Journal of World Business, 42(4), 401-417.

Cuervo-Cazurra, A., L. Ciravegna., M. Melgarejo. \& L. Lopez (2018), 'Home country uncertainty and the internationalizationperformance relationship: Building an uncertainty management capability', Journal of World Business, https://doi.org/10.1016/j.jwb.2017.11.002

Dunning, J. H (1988), 'The eclectic paradigm of international production: A restatement and some possible extension', Journal of International Business Studies, 19(1), 1-32.

Erdogan, A. I (2015). Which SMEs perceive access to finance as an obstacle to their operation? Evidence from Turkey. Journal of Economic and Social Development, 2(2), 13-19.

Fairlie, R. W., \& Robb, A. M. (2009). Gender differences in business performance: evidence from the characteristics of business owners survey. Small Business Economy, 33, 375-395.

Fernando, W. A. J. A. (2005). Gender subordination and women entrepreneurship. Master's thesis, Dublin Metropolitan University of Ireland, Dublin

Gashi, P., Hashi, I., \& Pugh, G. (2014). Export behaviour of SMEs in transition countries. Small Business Economics, 42(2), 407-435.

George, G., J. Wiklund. \& S. A. Zahra (2005). Ownership and the internationalization of small firms. Journal of Management, 31(2), 210-233. 
Ghoshal, S., \& Bartlett, C. A. (1990). The multinational corporation as an interorganizational network. Academy of Management Review, 15(4), 603-625.

Hambrick, D., \& Mason, P. A. (1984). Upper echelons: The organization as a reflection of its top managers. Academy of Management Review, $9(2), 193-206$.

Hambrick, D. C (2007). Upper echelons theory: an update. Academy of Management Review, 32(2), $334-343$.

Hair, J. F., Black, W. C., Babin, B. J., Anderson, R. E., \& Tatham, R. (2006). Multivariate data analysis. Uppersaddle River.

Herrmann, P., \& Datta, D. K. (2005). Relationships between top management team characteristics and international diversification: An empirical investigation. British Journal of Management, 16(1), 69-78.

Hibbert, E. (2000). The Globalization of Markets-How Can SMEs Compete?, Marketing Discussion Papers Business School, Middlesex University.

Ho, S. S. M., A. Y. Li., K. Tam. \& F. Zhang (2015). CEO gender, ethical leadership, and accounting conservatism. Journal of Business Ethics, 127(2), 351-370.

Hsu, C. -C (2006). Internationalization and performance: The S-curve hypothesis and product diversity effect. Multinational Business Review, 14(2), 29 - 46.

Hsu, W. T., Chen, H. L., \& Cheng, C. Y. (2013). Internationalization and firm performance of SMEs: The moderating effects of CEO attributes. Journal of World Business, 48(1), 1-12.

Hymer, S. (1976). The international operations of national firms: A study of direct investment. Boston, MA: MIT Press

Johanson, J., \& Vahlne, J. E. (1977). The internationalization process of the firm - a model of knowledge development and increasing foreign market commitments. Journal of International Business Studies, 8(1), 23-32.

Johanson, J., \& Vahlne, J. -E. (1990), 'The mechanism of internationalization', International Marketing Review, 7(4), 11-24.

Johanson, J., \& Vahlne, J. E. (2009). The Uppsala internationalization process model revisited: From liability of foreignness to liability of outsidership. Journal of International Business Studies, 40(9), 1411-1431.

Kabasakal, H., Aycan, Z. \& Farakas, F (2004). Women in management in Turkey, in Davidson, M.J. and Burke, R.J. (Eds), Women in Management Worldwide: Facts, Figures and Analysis, Gower, Aldershot.

Kabasakal, H., Aycan, Z., Farakas, F., \& Moden, C. (2011). Women in management in Turkey, in Davidson, M.J. and Burke, R.J. (Eds), Women in Management Worldwide: Progress and Prospects, Gower, Aldershopt

Lin, W. T., Liu, Y., \& Cheng, K. Y. (2011). The internationalization and performance of a firm: Moderating effect of a firm's behavior. Journal of International Management, 17(1), 83-95.

Maden, C. (2015). A gendered lens on entrepreneurship: Women entrepreneurship in Turkey. Gender in Management: An International Journal, 30(4), 312-331.

Riahi-Belkaoui, A. (1998). The effects of the degree of internationalization on firm performance. International Business Review, $7(3), 315-321$.

Tashman, P., Marano, V., \& Babin, J. (2019). Firm-specific assets and the internationalization-performance relationship in the US movie studio industry. International Business Review, 28(4), 785-795.

Tihayi, L., A. E. Ellstrand., C. M. Daily \& D. R. Dalton (2000). Composition of the top management team and firm international diversification. Journal of Management, 26(6), 1157-1177,

Vahlne, J. E., \& Johanson, J. (2017). From internationalization to evolution: The Uppsala model at 40 years. Journal of International Business Studies, 48(9), 1087-1102.

Xiao, S. S., Jeong, I., Moon, J. J., Chung, C. C., \& Chung, J. (2013). Internationalization and performance of firms in China: Moderating effects of governance structure and the degree of centralized control. Journal of International Management, $19(2), 118-137$.

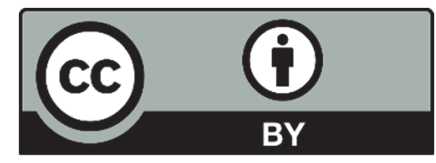

(C) 2020 by the authors; licensee Growing Science, Canada. This is an open access article distributed under the terms and conditions of the Creative Commons Attribution (CC-BY) license (http://creativecommons.org/licenses/by/4.0/). 